\title{
PENGARUH LATIHAN JOGGING TERHADAP (VO2Max)
}

\section{EFFECT OF JOGGING TRAINING ON (VO $\left.\mathrm{O}_{2} \mathrm{Max}\right)$}

\author{
Meyke Parengkuan, Sarjan Mile \\ Jurusan Pendidikan Jasmani, Kesehatan dan Rekreasi, Fakultas Olahraga dan Kesehatan, \\ Universitas Negeri Gorontalo \\ Kontak penulis: meykeparengkuan11@gmail.com
}

\begin{abstract}
ABSTRAK
Tujuan dari penelitian ini yaitu untuk mengetahui pengaruh latihan jogging terhadap kemampuan $\left(\mathrm{VO}_{2} \mathrm{Max}\right)$ Pada siswa SMP Negeri 13 Kota Gorontalo. Penelitian ini merupakan penelitian eksperimen dengan desain penelitian one group pretest dan posttest. Sampel dari penelitian ini adalah 24 siswa SMP Negeri 13 Kota Gorontalo didapatkan dengan Random Sampling. Instrumen penelitian ini menggunakan Bleep Test beserta klasifikasinya. Hasil dari penelitian ini mengungkapkan bahwa dengan latihan jogging, maka akan meningkatkan kemampuan Vo2 Max.
\end{abstract}

Kata Kunci: jogging; $\mathrm{VO}_{2} \mathrm{Max}$

\begin{abstract}
The purpose of this study was to determine the effect of jogging training on the ability $\left(\mathrm{VO}_{2} \mathrm{Max}\right)$ of students of SMP Negeri 13 Gorontalo City. This research is an experimental research with one group pretest and posttest research design. The sample of this study was 24 students of SMP Negeri 13 Gorontalo City obtained by random sampling. The research instrument used the Bleep Test and its classification. The results of this study reveal that jogging exercises will increase the ability of Vo2 Max.
\end{abstract}

Keywords: jogging; $\mathrm{VO}_{2} \mathrm{Max}$ 


\section{Pendahuluan}

Olahraga adalah segala kegiatan yang sistematis untuk mendorong, membina, serta mengembangkan potensi jasmani, rohani, dan sosial (Sumaryanto, 2015). Yang mana merupakan gerakan badan atau tubuh seseorang yang dilakukan oleh perorangan atau lebih kemudian melakukanya dengan rutin dan sistematis guna meningkatkan kebugaran jasmani seseorang tersebut (Hidayat, 2019). Olahrga juga adalah satu diantara cara utama untuk mereduksi stres dengan memotivasi secara positif terhadap seseorang (Hadjarati \& Haryanto, 2020). Olahraga juga satu tingkah laku aktif yang menggiatkan metabolisme serta mempengaruhi manfaat kelenjar didalam badan untuk menghasilkan sistem kebugaran jasmani (Sunarto Kadir, 2019) (Kadir, 2020) dalam usaha menjaga badan dari masalah penyakit dan stres dalam psikologisnya (Haryanto et al., 2021). Oleh karenanya, sangat disarankan bagi setiap orang untuk melakukan aktifitas olahraga dengan cara teratur serta terstruktur dengan baik dan rutin.

Masyarakat atau mahasiswa perlu melakukan aktifitas olahraga terkhusus joging untuk menyehatkan dan mengembalikan kesehatan tubuhnya (Haskell et al., 2007). Aktifitas olahraga jogging sangat bermanfaat bagi kesehatan, salah satu manfaatnya adalah untuk melancarkan aliran darah ke seluruh tubuh (Palar et al., 2015). Dengan melakukan aktifitas olahraga, akan mampu berkonsentrasi lebih lama dibandingkan dengan orang yang jarang melakukan aktifitas olahraga. Orang yang rutin melakukan olahraga joging tentu tubuhnya akan sehat sehingga dapat melakukan aktifitas sehari-hari dengan lancar. Olahraga jogging memegang peranan yang cukup penting untuk meningkatkan kualitas hidup seseorang. Olahraga untuk orang normal dapat meningkatkan kesegaran dan ketahanan fisik yang optimal.

Pada saat berolahraga terjadi kerjasama berbagai otot tubuh yang ditandai dengan perubahan sistim kardiorespirasi. pada sistem kardiovaskuler dan dapat meningkatkan kebugaran fisik (kemampuan untuk melakukan lebih banyak kegiatan dengan denyut jantung tertentu). Konsumsi Oksigen maksimal ( $\mathrm{VO}_{2} \mathrm{Max}$ ) adalah jumlah maksimal Oksigen yang dapat dikonsumsi selama aktivitas fisik yang intens sampai akhirnya terjadi kelelahan. Nilai $\mathrm{VO}_{2} \mathrm{Max}$ dapat dipengaruhi oleh genetik, jenis kelamin, usia dan aktifitas (latihan) (Sulistyo, 2015). Salah satu latihan fisik yang diketahui dapat meningkatkan daya tahan atau kebugaran fisik adalah jogging. Jogging pada rentang middle age sangat dianjurkan sehingga dapat menghasilkan efek latihan pada sistem kardiovaskuler dan dapat meningkatkan kebugaran fisik (kemampuan untuk melakukan lebih banyak kegiatan dengan denyut jantung tertentu) (Littman et al., 2005).

Pada observasi peneliti yang berhubungan dengan kegiatan perkuliahan olahraga praktek lapangan, peneliti melihat kegiatan siswa SMP Negeri 13 Kota Gorontalo dalam hal melakukan aktifitas olahraga jogging masih sangatlah lemah pada umumnya. Selain faktor kesadaran akan pentingnya olahraga yang berasal dari diri sendiri, faktor lain adalah kurangnya motivasi siswa SMP Negeri 13 Kota Gorontalo dalam berolahraga jogging, terkait dari masalh tersebut saya berupaya menerapkan latihan jogging untuk peningkatan kemampuan $\mathrm{VO}_{2} \mathrm{Max}$, sehingga judul penelitian ini yaitu mengetahui pengaruh latihan jogging terhadap kemampuan $\left(\mathrm{VO}_{2} \mathrm{Max}\right)$ Pada siswa SMP Negeri 13 Kota Gorontalo. Penelitian ini dirasa sangat penting, karena penelitian ini 
bisa juga sebagai sarana promosi untuk melakukan aktifitas olahraga jogging kepada masyarakat.

\section{Metode}

Penelitian ini merupakan penelitian eksperimen yang menggunakan desain penelitian one group pre-test post-test dengan sampel 24 siswa yang menggunakan Random Sampling. Instrumen tes dalam penelitian ini menggunakan Multistage-Fitness Test (MFT Test) atau bleep test dan tes pemahaman gerak melalui kuesioner.

Tabel 1. Klasifikasi tingkat Vo2 Max (Bleep Test)

\begin{tabular}{ccccccc}
\hline Usia & Buruk & Kurang & Sedang & Baik & Baik Sekali & Baik Sekali \\
\hline $13-19$ & $<35.0$ & $35.0-38.3$ & $38.4-45.1$ & $45.2-50.9$ & $51.0-55.9$ & $>55.9$ \\
\hline $20-29$ & $<33.0$ & $33.0-36.4$ & $36.5-42.4$ & $42.5-46.4$ & $46.5-52.4$ & $>52.4$ \\
\hline $30-39$ & $<31.5$ & $31.5-35.4$ & $35.5-40.9$ & $41.0-44.9$ & $45.0-49.4$ & $>49.4$ \\
\hline $40-49$ & $<30.2$ & $30.2-33.5$ & $33.6-38.9$ & $39.0-43.7$ & $43.8-48.0$ & $>48.0$ \\
\hline $50-59$ & $<26.1$ & $26.1-30.9$ & $31.0-35.7$ & $35.8-40.9$ & $41.0-45.3$ & $>45.3$ \\
\hline $60+$ & $<20.5$ & $20.5-26.0$ & $26.1-32.2$ & $32.3-36.4$ & $36.5-44.2$ & $>44.2$ \\
\hline
\end{tabular}

Adapun teknik pengumpulan data menggunakan uji statistik dengan persyaratan uji normalitas, uji homogenitas dan hipotesis statistik.

\section{Hasil}

Penelitian eksperimen ini telah dilaksanakan di Sekolah SMP N 13 Kota Gorontalo. Peneliti melakukan pengamatan difokuskan pada siswa kelas VII B SMP Negeri 13 Kota Gorontalo. Adapun hasilnya secara statistik dapat dapat dideskripsikan sebagai berikut:

Tabel 2. Deskripsi Statistik

\begin{tabular}{lcc}
\hline \multicolumn{1}{c}{ Statistik } & Pretest & Posttest \\
\hline $\mathrm{N}$ & 24 & 24 \\
\hline Buruk (Vo2 Max) & 15 & 0 \\
\hline Kurang (Vo2 Max) & 4 & 2 \\
\hline Sedang (Vo2 Max) & 5 & 12 \\
\hline Baik (Vo2 Max) & 0 & 8 \\
\hline Baik Sekali (Vo2 Max) & 0 & 2 \\
\hline Mean & 30.4458 & 40.2333 \\
\hline Std. Deviasi & 6.47544 & 7.28684 \\
\hline Maks & 42.60 & 52.60 \\
\hline Min & 22.40 & 30.90 \\
\hline
\end{tabular}
berikut:

Setelah mengetahui hasil uji deskriptif statistik, maka dilakukan uji normalitas sebagai 


\begin{tabular}{lccc}
\hline \multicolumn{1}{c}{ Kelompok Data } & Sig. (2-tailed) & Sig & Keterangan \\
\hline Pretest & 0,200 & 0,05 & Normal \\
\hline Posttest & 0,182 & 0,05 & Normal \\
\hline
\end{tabular}

Dari tabel tersebut diketahui bahwa Sig. (2-tailed) nilai pretest adalah 0,200 maka lebih besar dari 0,05 sehingga data berdistribusi normal. Data Sig. (2-tailed) posttest adalah 0,182 maka lebih besar dari 0,05 sehingga data berdistribusi normal. Kemudian langkah berikutnya adalah uji homogenitas sebagai berikut:

Tabel 4. Uji Homogenitas

\begin{tabular}{cccc}
\hline Kelompok Data & Sig. (2-tailed) & Sig & Keterangan \\
\hline Jogging & 0,06 & 0,05 & Homogen \\
\hline
\end{tabular}

Dari tabel tersebut diketahui bahwa penelitian ini homogen karena menunjukkan nilai Sig. (2-tailed) lebih besar daripada 0,05 atau (Sig.>0,05). Setelah melalui uji homogenitas, maka penelitian selanjutnya uji beda rata-rata (Paired sample t-test) sebagai berikut:

Tabel 5. Uji Beda Rerata (Paired sample t-test)

\begin{tabular}{ccccc}
\hline Data & Kelompok & SD & Mean & Sig. (2-tailed) \\
\hline Vo2 Max & Pretest & 6.47544 & 30.4458 & 0,00 \\
\hline & Posttest & 7.28684 & 40.2333 & 0,00 \\
\hline
\end{tabular}

Berdasarkan pada hasil pengujian statistik ditemukan bahwa nilai Sig. (2-tailed) 0,00 < 0,05 , yang berarti keduanya terdapat perbedaan pretest dan posttest. Setelah melakukan uji rerata, maka pengujian hipotesis dilakukan untuk mengetahui perbedaan yang signifikan hasil VO2Max sebelum dan sesudah melalui latihan jogging, sebagai berikut:

Tabel 6. Hasil Uji Hipotesis (Paired Sample Test)

\begin{tabular}{lccccc}
\hline Hasil & Mean & SD & T & df & Sig. (2-tailed) \\
\hline Pretest- Posttest & -9.78750 & 3.49587 & -13.716 & 23 & .000 \\
\hline
\end{tabular}

Dari tabel tersebut, maka diketahui bahwa ada perbedaan yang signifikan hasil VO2Max sebelum dan sesudah melalui latihan jogging pada siswa SMP Negeri 13 Kota Gorontalo. Perbedaan sebesar 9,787 (dimana beda mean antara sesudah dan sebelum perlakuan/treatment).

\section{Pembahasan}

Penelitian eksperimen ini telah dilaksanakan di Sekolah SMP N 13 Kota Gorontalo menghasilkan suatu temuan yang menegaskan bahwa dengan latihan jogging akan mempengaruhi tingkat $\mathrm{VO}_{2} \mathrm{Max}$. Hasil penelitian ini sesuai dengan penelitian sebelumnya yang mengungkapkan bahwa dengan latihan aerobik yang salah satunya adalah jogging, akan meningkatkan kapasitas $\mathrm{VO}_{2} \mathrm{Max}$ sampai $21,7 \%$ (Watulingas, 2013). Penelitian lainnya yang berkaitan dengan aktivitas aerobik terhadap $\mathrm{VO}_{2} \mathrm{Max}$ juga dilakukan untuk Atlet yang 
didapatkan kesimpulan bahwa latihan aerobik dapat meningkatkan kapasitas $\mathrm{VO}_{2} \mathrm{Max}$ (Festiawan et al., 2020).

Penelitian lain yang mendukung hasil dari penelitian ini juga membuktikan bahwa konsumsi Oksigen akan meningkat seiring dengan latihan aerobik (DiStefano, 2012). Dengan mengkonsumsi Oksigen yang sebanyak banyaknya, maka seseorang akan mengalami adaptasi yang menyebabkan kapasitas maksimal dalam penyerapan Oksigen akan menjadi lebih efisien.

\section{Kesimpulan}

Kesimpulan yang didapatkan dalam penelitian ini yaitu latihan jogging akan mempengaruhi konsumsi Oksigen seseorang yang dapat diartikan bahwa tingkat $\mathrm{VO}_{2} \mathrm{Max}$ akan semakin meningkat.

\section{Referensi}

DiStefano, P. J. (2012). Training Benefits of Maximal Oxygen Consumption using an AntiGravity Treadmill versus a Terrestrial Treadmill. ProQuest Dissertations and Theses.

Festiawan, R., Suharjana, S., Priyambada, G., \& Febrianta, Y. (2020). High intensity interval training dan fartlek training: Pengaruhnya terhadap tingkat VO2 Max. Jurnal Keolahragaan. https://doi.org/10.21831/jk.v8i1.31076

Hadjarati, H., \& Haryanto, A. I. (2020). Motivasi Untuk Hasil Pembelajaran Senam Lantai. Multilateral Jurnal Pendidikan Jasmani Dan Olahraga. https://doi.org/10.20527/multilateral.v19i2.8646

Haryanto, A. I., Gani, A. A., Ramadan, G., Samin, G., Fataha, I., \& Kadir, S. S. (2021). Shooting Athlete Mental Training. JUARA: Jurnal Olahraga, 6(1). https://doi.org/https://doi.org/10.33222/juara.v6i1.1188

Haskell, W. L., Lee, I. M., Pate, R. R., Powell, K. E., Blair, S. N., Franklin, B. A., MacEra, C. A., Heath, G. W., Thompson, P. D., \& Bauman, A. (2007). Physical activity and public health: Updated recommendation for adults from the American College of Sports Medicine and the American Heart Association. In Medicine and Science in Sports and Exercise. https://doi.org/10.1249/mss.0b013e3180616b27

Hidayat, S. (2019). Kesegaran Jasmani Siswa 10-12 Tahun Se-Kota. Jambura Journal of Sports Coaching.

Kadir, Sunarto. (2019). Korelasi Antara Konsumsi Rokok Dengan Tingkat. Jambura Journal of Sports Coaching.

Kadir, Suprianto. (2020). Evaluation Of Vo2max Atlet Karate In The Covid-19 Pandemic Era. Jambura Journal of Sports Coaching. https://doi.org/10.37311/jjsc.v2i2.7058

Littman, A. J., Kristal, A. R., \& White, E. (2005). Effects of physical activity intensity, frequency, and activity type on $10-y$ weight change in middle-aged men and women. International Journal of Obesity. https://doi.org/10.1038/sj.ijo.0802886

Palar, C. M., Wongkar, D., \& Ticoalu, S. H. R. (2015). Manfaat Latihan Olahraga Aerobik Terhadap Kebugaran Fisik Manusia. Jurnal E-Biomedik. https://doi.org/10.35790/ebm.3.1.2015.7127

Sulistyo. (2015). Tinjauan Kemampuan Volume Oksigen Maksimal (Vo2 Max) Atlet Pencak Silat Pusat Pendidikan Dan Latihan Pelajar (PPLP) Sumatera Barat Tahun 2015. Universitas Negeri Padang.

Sumaryanto, S. (2015). Perspektif Filsafat Olahraga Dalam Mewujudkan Masyarakat Sehat. MEDIKORA. https://doi.org/10.21831/medikora.v0i1.4646

Watulingas, I. (2013). Pengaruh Latihan Fisik Aerobik Terhadap Vo2 Max Pada. E-Biomedik. 